\title{
Sulfate reduction and alterability of sulfur species in sediments of an estuary with irregular hydrological regime
}

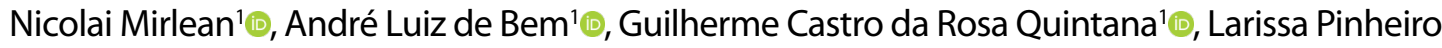 \\ $\operatorname{Costa}^{\top} \odot$, Alexandre Henrique Ferraz ${ }^{1 *}{ }_{\odot}$ \\ ${ }^{1}$ Universidade Federal do Rio Grande - Instituto de Oceanografia (km 8 - Av. Itália - Carreiros - Rio Grande - $96203-900$ - RS - Brazil) \\ *Corresponding author: aleferraz.h@gmail.com
}

\section{Abstract}

The irregular hydrological regime in Patos Lagoon estuary has been suggested as having a distinctive influence on sulfur speciation in sediments. We performed an investigation for different prolonged hydrological conditions focusing on the distribution of sulfides (acid volatile sulfide (AVS), chromium reducible sulfide (CRS), and Free-S2-) in sediment cores from salt marsh and non-vegetated shallow zone. Significant differences in sulfides content and distribution between the different hydrological periods were found. The predominance of more reducing conditions was observed during the freshwater period. It reflects a higher total reducible inorganic sulfur (TRIS) content in this period, with a great accumulation of AVS in sediments (> $100 \mathrm{mg} \mathrm{kg}^{-1}$ ). In the maximum salinity period, more oxidizing conditions prevailed, which significantly decreased the concentrations of metastable sulfides. The intense bioirrigation process exerts control over sulfide formation and distribution, which is as important as that exerted by the variations of the hydrological regime.

Descriptors: Sulfides formation, Saltmarsh sediment, Hydrological regime, River dominated estuary.

\section{INTRODUCTION}

The diagenetic transformations of sulfur (S) play a major role in coastal and estuarine sediments chemistry, with significant influence on carbon (Hyun et al., 2007), metals (Otero et al., 2009; Hernández-Crespo and Martín, 2013; Yang et al., 2013), and oxygen cycles (Brüchert et al., 2003). The oxidation of organic matter by sulfate-reducing bacteria during early diagenesis is the initial step for all those transformations. The redox vertical zonation and the rate of sulfate reduction in sediments are controlled by several environmental conditions, such as the availability of dissolved oxygen (DO) and other electron acceptors (i.e. $\mathrm{Mn}(\mathrm{IV}), \mathrm{NO}_{3}{ }^{-}$and $\mathrm{Fe}(\mathrm{III}))$, content and reactivity of sedimentary organic

Submitted on: 28/March/2020

Approved on: 30/August/2020

Associate Editor: Luigi Jovane

Editor: Rubens M. Lopes carbon (OC), sedimentation rate, grain size, and sulfate availability (Stumm and Morgan, 1996; Jørgensen and Kasten, 2005).

The products of bacterial sulfate reduction are the free sulfides (i.e., $\mathrm{H}_{2} \mathrm{~S}, \mathrm{HS}^{-}, \mathrm{S}^{2-}$ ), which determine the main transformation paths of sedimentary sulfur as well as iron under anaerobic conditions (Vairavamurthy et al., 1995). Iron sulfides are the main components of the Total Reduced Inorganic Sulfur (TRIS) pool in marine and estuarine sediments (Jørgensen and Kasten, 2005; Bianchi, 2007). Operationally, these insoluble sulfides tend to be divided into two groups according to their reactivity and stability in the system: Acid Volatile Sulfides (AVS), which consist mainly of metastable species of insoluble iron sulfides such as Mackinawite (FeS) and Greigite $\left(\mathrm{Fe}_{3} \mathrm{~S}_{4}\right.$ ) (Morse and Cornwell, 1987; Rickard and Morse, 2005) and Chromium Reducible Sulfur (CRS), which includes the most stable forms of reduced sedimentary sulfur, such as elemental sulfur $\left(\mathrm{S}^{0}\right)$ and pyrite $\left(\mathrm{FeS}_{2}\right)$. 
Berner (1970) suggested that pyrite formation in sediments is limited by three main processes: (1) organic matter input, (2) sulfate concentration, and (3) availability of reactive iron. In general, these processes can be defined as factors that limit the formation of all iron sulfide species. The author also describes that the relative importance of those factors will depend on the environment. In noneuxinic marine environments, the content of organic matter controls the formation of iron sulfides, whereas in freshwater environments, the low sulfate concentration acts as the main limiting factor to the formation of iron sulfides (Berner, 1970).

In euxinic marine environments, where the sulfate reduction rates are high, the formation of iron sulfides is mainly controlled by the availability of reactive iron (Berner, 1970). However, none of those limiting factors tend to be observed in estuarine areas, which are known as transitional environments where mixing of marine and continental waters occurs (Windom et al., 1999). Those factors lead to an increase of metals, sulfate ion, and organic matter, which facilitates sulfate reduction and, consequently, metal sulfide formation in bottom sediments (Jørgensen and Kasten, 2005). Under such conditions, other variables such as temperature and bioturbation/bioirrigation must be included to better understand the sulfate reduction intensity and zonation, as well as local and temporal variations of sulfides in sediments (MarvinDiPasquale and Capone, 1998; Panutrakul et al., 2001; Marvin-DiPasquale et al., 2003; Koretsky et al., 2008; Yang et al., 2013; Wang et al., 2015).

Temperature, which may increase bacterial metabolism, and bioturbation are parameters that initially affect the oxygen availability in sediments, thus indirectly conditioning diagenetic processes (Kristensen et al., 1992; Sundby, 2006; Ferreira, 2010; Zhang et al., 2013). In the Patos Lagoon estuary, Southern Brazil, oxygen availability in sediments is strongly associated with local hydrodynamics. This river-dominated microtidal estuary presents an irregular hydrological regime throughout the year, which is mainly controlled by the wind and river discharge (Costa et al., 2003; Möller et al., 2009). On average, maximum salinity conditions are observed in the estuarine waters during austral summer and fall; and low salinity conditions during winter and spring (Marques et al., 2010).
Dissolved oxygen varies from saturated (under low salinities) to supersaturated (under maximum salinities) in this estuary (Windom et al., 1999). More specifically, DO in the estuary is close to $100 \%$ saturation during maximum salinity conditions and, values can decrease to $70 \%$ rarely, during low salinity periods (Niencheski et al., 1999). Hydrological regimes also affect the water level in the estuary, which leads to flooding of some parts of the saltmarshes in the estuary (Costa et al., 2003; Vaz et al., 2006; Möller et al., 2009).

Other studies demonstrated that the change between freshwater and maximum salinity periods exerts a long-term impact on arsenic (As) distribution in sediments of Patos Lagoon estuary (Costa et al., 2017) and salt-marsh vegetation dieback due to drastic changes of geochemical characteristics (e.g., $\mathrm{pH}, \mathrm{TRIS}$ ) of surface sediment (Mirlean and Costa, 2017). We hypothesize that since the variations in the hydrological regime influence the water level and the DO availability in the estuary, it may also influence the redox zonation in the sediments that would directly affect the sulfides distribution through the sediment profiles. However, research on the spatial-temporal distribution of sulfides in estuaries with an irregular hydrologic regime (e.g., Patos Estuary) is still rare.

This study aims to investigate the distribution of different forms of sulfides in sediment profiles during distinct hydro-chemical conditions in the Patos Lagoon estuary (i.e., long-term freshwater and maximum salinity periods). We chose to conduct this research in two different environmental settings - a salt marsh and a non-vegetated zone -, making it possible to identify important processes related to water level variations and bioturbation that locally contribute to the temporal variation of sulfide forms in sediments.

\section{MATERIALS AND METHODS}

\section{Description Of THE STUdy AREA}

Patos Lagoon is considered the largest "choked" coastal lagoon in the world (Kjerfve, 1994). Its southern portion includes an estuarine zone $\left(\sim 900 \mathrm{~km}^{2}\right)$ that discharges directly into the Atlantic Ocean (Figure 1). The cities of Rio Grande and São José do Norte are located on the margins of this estuary as well as the Rio Grande Harbor, the second largest harbor in cargo movements in Brazil. 


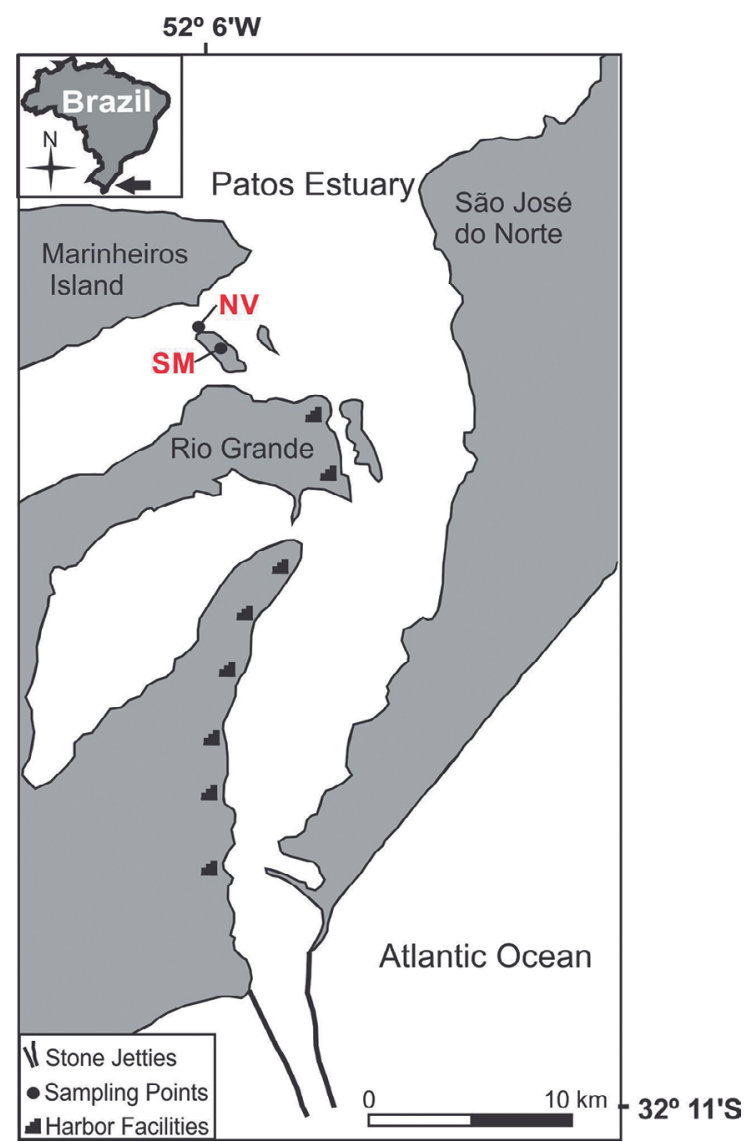

Figure 1. Patos Lagoon estuary showing our sampling locations. SM: Salt Marsh; NV: Non-Vegetated zone.

The main contributing rivers are Taquari and Jacuí, which flow through the Guaíba River and Camaquã River into the lagoon (Marques et al., 2009).

The study was conducted at two sites located in the center of the estuary, at a distance of about $25 \mathrm{~km}$ from its mouth: a salt marsh (SM) located on Pólvora Island and a non-vegetated zone (NV) located between Pólvora Island and Marinheiros Island (Rio Grande, Brazil, 32 $01^{\prime} \mathrm{S}, 52^{\circ} 06^{\prime} \mathrm{W}$; Figure 1). The estuarine region is characterized by a humid subtropical to temperate climate and a microtidal regime (i.e., tidal range $<0.5 \mathrm{~m}$ ). The local hydrodynamics is mainly controlled by the combination of three effects (Möller et al., 1996): the wind effect on the water surface of the estuary (local wind effect); the wind effect on the entire coastal region (non-local wind effect); and the river discharge in the northern region of the lagoon, whose intensity is directly associated with the amount of atmospheric precipitation on the watershed $\left(200,000 \mathrm{~km}^{2}\right)$.
The estuary tends to present maximum salinity conditions during austral summer and fall, associated with a lower river flow (i.e., dry season) and low salinity conditions during austral winter and spring when - despite the dominance of southern winds - high river flow (i.e., rainy season) makes salt intrusion difficult (Marques et al., 2010). The Patos Lagoon is located between two large Lagoon-Barrier depositional systems formed as a consequence of sea-level variations during the Pleistocene and Holocene, respectively (Ivanoff et al., 2020). The bottom sediments from Patos Lagoon estuary are mainly siliciclastic with grain size ranging from silt to sand and, in total, ten local sedimentary facies were previously identified: silt, sandy silt, silty clay, silty sand, mixed, clayed silt, sand, clayed sand, sandy clay and clay (Antiqueira and Calliari, 2005).

\section{SAMPLING}

Sampling was performed during two periods: i) September 2016, when the estuary was dominated by river discharge (i.e., freshwater period, with salinity of 0-5 PSU), and ii) April 2017, corresponding to the period of maximum salinity waters in the estuary (i.e., 10 - 20 PSU). The salinity conditions for each period described above had prevailed in the region for about a month before sampling according to the oceanographic monitoring system network (SiMCosta) of Federal University of Rio Grande. During each sampling period, one sediment core was collected from each site (Figure 1), using precleaned PVC tubes $(8 \mathrm{~cm}$ in diameter and $60-66 \mathrm{~cm}$ long). The sediment cores were collected manually, by two scientists on foot, using simple tools (i.e., sledgehammer, hacksaw, and adhesive tape).

After sampling, the sediment cores were hermetically sealed and transported in an upright position to the laboratory and stored at $4{ }^{\circ} \mathrm{C}$. Within 24 hours after sampling, the sediment cores were longitudinally opened and each part was immediately sealed with plastic film, being divided into subsamples. One half was used for electrochemical (i.e., $\mathrm{pH}$, conductivity, Eh, and Free-S2-) and OC analyses, whereas the other half was sliced every $2 \mathrm{~cm}$ and each cut was rapidly hermetically sealed and frozen for subsequent sulfides (i.e., AVS and CRS) distillation. 
The sediment core in the SM location was sampled on the edge of a ring-shaped structure of Spartina densiflora. The SM area is subjected to random variations of water level within the estuary (Costa et al., 2003; Mirlean and Costa, 2017). During sampling, SM sediments from the freshwater period were underwater (i.e., about $10 \mathrm{~cm}$ of water column). On the other hand, they were sporadically exposed to subaerial conditions during the maximum salinity period. In both periods, burrowing crabs (Neohelice granulata) were observed in the SM site. The sediment core from the NV site was sampled in shallow (i.e., about $1 \mathrm{~m}$ of water column) non-vegetated marginal zone. The shallow zone was permanently underwater during both sampling periods. The NV and SM locations were marked by poles and the distance between the cores collected at the sampling points in September and April was about $0.5 \mathrm{~m}$.

\section{Analytical procedures}

The redox potential (Eh) was directly measured every $2 \mathrm{~cm}$ in the sediments, at room temperature, with a combined Pt-electrode Analion ${ }^{\oplus}$. Conductivity and $\mathrm{pH}$ were measured in filtered $\left(0.45 \mu \mathrm{m}\right.$ Milipore ${ }^{\circledR}$ membrane) superficial $(0-20 \mathrm{~cm}$ depth) interstitial waters extracted from the sediment subsamples by centrifugation (3000 rpm). The analyses of free sulfides (Free-S2-) in the pore water were also performed in intervals of $2 \mathrm{~cm}$ using a Hanna ${ }^{\oplus} 9616$ BNC lonplus silver/sulfide electrode coupled to ISE/pH/mV/Eh/ temperature Orion ${ }^{\mathrm{TM}} 290^{\mathrm{a}}$ meter (model 209a; Brooks, 2001). The electrode has a concentration range that varies from 0.0 to $19.9 \mathrm{~mol} \mathrm{~L}^{-1}\left(\mathrm{~S}^{2-}\right)$ and relative precision of $+0.5 \%$. A basic antioxidant solution for sulfides (Sulfide Antioxidant Buffer - SAOB, Hanna Intruments $\left.{ }^{\oplus}\right)$ and a sulfide standard $\left(\mathrm{Na}_{2} \mathrm{~S} .9 \mathrm{H}_{2} \mathrm{O}\right)$ were previously made and used for calibration of the ionselective electrode. The electrode was calibrated from a three-point calibration curve $(100,1000$, $10000 \mu \mathrm{mol} . \mathrm{L}^{-1}$ ) (Brooks, 2001). Measurement was performed in a solution containing $2 \mathrm{~g}$ of sediment subsamples and $5 \mathrm{~mL}$ of SAOB.

After that, the same half of the core was sectioned into $4-\mathrm{cm}$ thick slices to perform the analysis of $\mathrm{OC}$ content in the sediments. Specifically, $30 \mathrm{mg}$ of powdered dry sediment sample was employed in $O C$ analysis using a TOC - VCPH, model SSM - 5000A, SHIMADZU ${ }^{\circledR}$. This device performs organic carbon determination following the $680^{\circ} \mathrm{C}$ combustion catalytic oxidation method, developed by SHIMADZU ${ }^{\circledR}$. The $\mathrm{CO}_{2}$ generated by the $\mathrm{OC}$ combustion is detected using an infrared gas analyzer (NDIR). This method has a detection limit of $4 \mathrm{mg}^{\mathrm{kg}} \mathrm{g}^{-1}$ and, the results are presented in percentage of organic carbon of dried sediment, and the relative standard deviation (\%RSD) was less than $5 \%$ for triplicate analyses.

The AVS and CRS analyses were performed in 2-cm thick subsamples throughout the sediment core. The AVS content was determined according to the standard USEPA 821-R-100 methodology (USEPA, 1991) using still-frozen samples. The content of free sulfides was subtracted from the AVS content. The TRIS determination followed the CRS analytical protocol according to the methodology described in the literature (Fossing and Jørgensen, 1989). CRS concentrations reported in this study were subtracted by the AVS and Free-S2concentrations; thus, the CRS term here only refers to the stable forms of insoluble sulfides, in contrast to the AVS term, which refers to the metastable species (Rickard and Morse, 2005). The quantification of AVS and CRS content was via iodometry. The relative standard deviation (RSD\%) for the duplicate analyses in $20 \%$ of the analyzed samples was $~ 5 \%$ and $~ 10 \%$ for CRS and AVS, respectively.

The sediment grain size analysis was performed at 4 $\mathrm{cm}$ intervals using the standard method (ABNT, 1987). Sediment grain size and OC content were analyzed only for the freshwater period samples, since those parameters may not vary significantly between each period of sampling.

\section{Statistical analyses}

The correlation between the target variables were based on the Pearson correlation with a significant level defined in $p<0.01$. Analysis of variance (ANOVA) and post hoc test (Fisher LSD, $p<0.05$ ) were applied to reveal the statistical difference between mean concentrations of the studied parameters. The analyses were performed using the Statistica ${ }^{\circledR} 10.0$ software.

\section{RESULTS}

\section{Vertical Distribution OF GRAIN SIZE AND ORGaNIC CARBON CONTENT}

The percentage of fine grain sediment (i.e., $<63$ $\mu \mathrm{m}$ ) varied from 20.84 to $61.17 \%$ in core SM, and 
from 12.42 to $36.80 \%$ in core NV (Table 1; Figure 2). Mean percentage of fine grain was $38.70 \pm 12.54$ the salt marsh core (SM) and $21.12 \pm 9.93$ in the non-vegetated shallow zone core (NV) (Table 1). At the NV site, the level of fine-grained fractions slightly increased with depth, presenting the highest values at the bottom of the profile $(28-38 \mathrm{~cm}$ ) (Figure 2). At the SM site, the highest levels of fine-grained sediments occurred in the middle of the core, with a peak (61.17\%) between $20-24$ $\mathrm{cm}$ (Figure 2).

As expected, the SM sediments showed much higher mean $\mathrm{OC}$ content $(1.63 \pm 1.70 \%$ of $\mathrm{OC})$ than the NV sediments $(0.36 \pm 0.10 \%$ of OC) (Table 1$)$. The OC content decreased with depth in the SM core (Figure 2), with highest values in the uppermost few centimeters (up to $5.13 \%$ ), and getting as low as 0.33 $\%$ at the bottom. In the NV core, the OC content is relatively low $(<1 \%)$ and remained almost constant throughout the profile (Figure 2 ), with a subtle increase at the bottom.

\section{CONDUCTIVITY AND PH OF SUPERFICIAL PORE WATER}

The mean conductivity values in SM superficial pore water $(0-20 \mathrm{~cm}$ depth) was greater during the

Table 1. Percentages of Fine Grains and OC for SM and NV locations. The upper values are the percentage range, and the mean $\pm S D$ is presented within parentheses.

\begin{tabular}{ccc}
\hline Parameter & SM & NV \\
\hline Fine Grain (\%) & $\frac{20.84-61.17}{(38.70 \pm 12.54)}$ & $\frac{12.42-36.80}{(21.12 \pm 9.93)}$ \\
OC (\%) & $\frac{0.33-5.13}{(1.63 \pm 1.70)}$ & $\frac{0.26-0.61}{(0.36 \pm 0.10)}$ \\
\hline
\end{tabular}

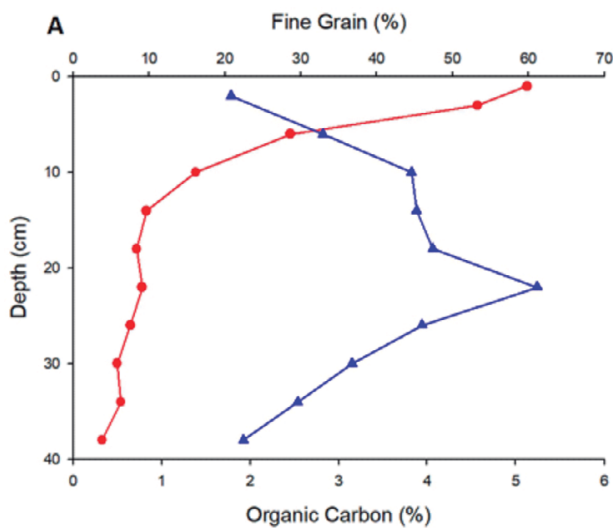

maximum salinity period $\left(27.32 \pm 1 \mathrm{mS} \mathrm{cm}^{-1}\right.$; Table 2$)$ in comparison to that of the freshwater period (10.76 $\pm 1.46 \mathrm{mS} \mathrm{cm}^{-1}$; Table 2), corroborating the influence of the irregular regime of Patos Lagoon estuary. In general, $\mathrm{pH}$ values in pore water at SM location during the maximum salinity period (6.1 to 7; Table 2) were lower than those found during the freshwater period (7 to 7.75; Table 2). The mean conductivity of superficial pore water at NV was much higher for the maximum salinity period (41.1 $\pm 6.7 \mathrm{mS} \mathrm{cm}^{-1}$; Table 3 ) in comparison to that of the freshwater period $(12.1 \pm 1.47 \mathrm{mS}$ $\mathrm{cm}^{-1}$; Table 3). The $\mathrm{pH}$ values were slightly lower during the freshwater period, ranging from 6.8 to 7.6 in comparison to the maximum salinity period (7.4 to 7.6 ; Table 3; Figure 3).

Vertical distribution and temporal Variation of EH AND SULFIDES IN THE SALTMARSH SEDIMENTS

Redox potential (Eh) varied from -252.0 to -69.0 $\mathrm{mV}$ for sediments from core SM during the freshwater period, and from -181.0 to $82.0 \mathrm{mV}$ during the maximum salinity period (Table 2; Figure 4 ). The mean Eh values for the freshwater period $(-118.0 \pm 64.0$ $\mathrm{mV}$ ) indicate that the sediments are more reducing, whereas sediments from the maximum salinity period presented more oxic conditions (-61.1 $\pm 84.4 \mathrm{mV}$; Table 2).The Eh profile with depth (Figure 4) points to greater variations in the uppermost layers. For the freshwater period, the uppermost portion of the profile (0-10 $\mathrm{cm}$ ) presented highly reducing conditions (Figure 4), and below $10 \mathrm{~cm}$ the Eh remained relatively stable. For the maximum salinity period, the first $10 \mathrm{~cm}$ of the profile presented oxidizing conditions with Eh values

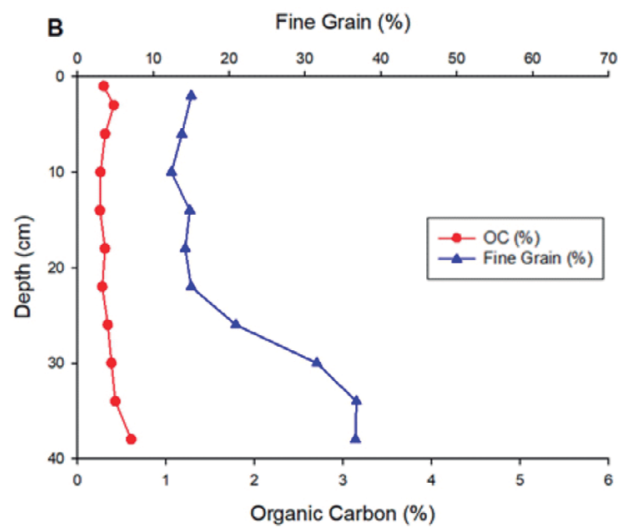

Figure 2. Fine grain (\%) and organic carbon (\%) as a function of depth for sediment cores collected from the SM (A) and NV (B) sites. 
Table 2. Geochemical parameters (Free-S2-; AVS, CRS, Eh, $\mathrm{pH}$ and conductivity) for SM location. The upper values are the concentration range, and the mean \pm SD is presented within parentheses.

\begin{tabular}{|c|c|c|}
\hline Parameter & Freshwater period & $\begin{array}{c}\text { Maximum salinity } \\
\text { period }\end{array}$ \\
\hline $\begin{array}{l}{ }^{*} \text { Free- } S^{2-} \\
\left(\mu \mathrm{mol} \mathrm{L}{ }^{-1}\right)\end{array}$ & $\frac{4.87-35.18}{(14.10 \pm 9.43)}$ & $\frac{4.46-18.09}{(9.94 \pm 3.97)}$ \\
\hline $\begin{array}{c}{ }^{*} \text { AVS } \\
\left(\mathrm{mg} \mathrm{kg}^{-1}\right)\end{array}$ & $\frac{38.20-145.18}{(75.45 \pm 35.32)}$ & $\frac{12.24-206.16}{(81.25 \pm 81.87)}$ \\
\hline $\begin{array}{c}{ }^{*} \mathrm{CRS} \\
\left(\mathrm{mg} \mathrm{kg}{ }^{-1}\right)\end{array}$ & $\frac{534.35-3858.53}{(1948.77 \pm 1428.99)}$ & $\frac{421.47-1126.06}{(715.26 \pm 210.31)}$ \\
\hline${ }^{*} \operatorname{Eh}(\mathrm{mV})$ & $\frac{-252.0--69.0}{(-118.0 \pm 64.0)}$ & $\frac{-181.0-82.0}{(-61.1 \pm 84.4)}$ \\
\hline${ }^{* *} \mathrm{pH}$ & $\frac{7-7.75}{(7.41 \pm 0.25)}$ & $\frac{6.1-7}{(6.58 \pm 0.35)}$ \\
\hline $\begin{array}{l}{ }^{* *} \text { Conductivity } \\
\left(\mathrm{mS} \mathrm{cm} \mathrm{cm}^{-1}\right)\end{array}$ & $\frac{8.63-13.11}{(10.76 \pm 1.46)}$ & $\frac{25.9-28.6}{(27.32 \pm 1)}$ \\
\hline
\end{tabular}

* 0-40 cm depth; ${ }^{* *} 0-20 \mathrm{~cm}$

Table 3. Geochemical parameters (Free-S2-- AVS, CRS, Eh, pH and conductivity) for NV location. The upper numbers are the concentration range, and the mean \pm SD is presented within parentheses.

\begin{tabular}{|c|c|c|}
\hline Parameter & Freshwater period & $\begin{array}{l}\text { Maximum salinity } \\
\text { period }\end{array}$ \\
\hline $\begin{array}{l}{ }^{*} \text { Free- } S^{2-} \\
\left(\mu \mathrm{mol} \mathrm{L}{ }^{-1}\right)\end{array}$ & $\frac{9.98-387.87}{(95.49 \pm 116.17)}$ & $\frac{3.73-187.81}{(65.50 \pm 42.99)}$ \\
\hline $\begin{array}{c}{ }^{*} \mathrm{AVS} \\
\left(\mathrm{mg} \mathrm{kg}{ }^{-1}\right)\end{array}$ & $\frac{3.60-299.65}{(62.27 \pm 99.95)}$ & $\frac{1.61-24.90}{(11.52 \pm 7.54)}$ \\
\hline $\begin{array}{c}{ }^{*} \mathrm{CRS} \\
\left(\mathrm{mg} \mathrm{kg}{ }^{-1}\right)\end{array}$ & $\frac{95.90-4554.79}{(1235.89 \pm 1641.70)}$ & $\frac{12.46-3290.38}{(809.48 \pm 1103.38)}$ \\
\hline${ }^{*}$ Eh (mV) & $\frac{-301.0-45.0}{(-134.7 \pm 91.3)}$ & $\frac{-280.0-21.0}{(-139.9 \pm 71.52)}$ \\
\hline${ }^{* *} \mathrm{pH}$ & $\frac{6.8-7.6}{(7.2 \pm 0.3)}$ & $\frac{7.4-7.6}{(7.48 \pm 0.05)}$ \\
\hline $\begin{array}{l}\text { **Conductivity } \\
\left(\mathrm{mS} \mathrm{cm}^{-1}\right)\end{array}$ & $\frac{10.31-14}{(12.1 \pm 1.47)}$ & $\frac{33.43-51.9}{(41.1 \pm 6.7)}$ \\
\hline
\end{tabular}

reaching $82.0 \mathrm{mV}$ (Figure 4). Between $10-20 \mathrm{~cm}$, Eh showed values similar to the ones observed in the freshwater period. Below $20 \mathrm{~cm}$, the redox potential in the sediment indicated more reducing conditions respect to the freshwater period (Figure 4).
Free sulfide concentrations were higher for the freshwater period (i.e., between 4.87 and $35.18 \mu \mathrm{mol}$ $\mathrm{L}^{-1}$; Table 2), whereas Free- $\mathrm{S}^{2-}$ concentrations for the maximum salinity period ranged between 4.46 and $18.09 \mu \mathrm{mol} \mathrm{L}^{-1}$ (Table 2). The Free- $\mathrm{S}^{2-}$ variations were more significant in the uppermost layers $(0-10 \mathrm{~cm}$; Figure 4) for both sampling periods. A considerable decrease of free sulfide levels starting from $10 \mathrm{~cm}$ of depth was observed for the freshwater period, while a relatively constant distribution throughout the profile is noticed in the maximum salinity period (Figure 4).

In contrast, AVS mean contents were slightly higher for the maximum salinity period $(81.25 \pm 81.87)$, with concentrations between 12.24 and 206.16 $\mathrm{mg} \mathrm{kg}^{-1}$ (Table 2), whereas AVS mean contents for the freshwater period were $(75.32 \pm 35.32)$, with concentrations ranging between 38.20 to $145.18 \mathrm{mg}$ $\mathrm{kg}^{-1}$ (Table 2). In the uppermost layers of the profiles $(0-10 \mathrm{~cm})$, the AVS distribution showed a similar pattern when compared to Free-S2-, with higher concentrations in the freshwater period in comparison to the maximum salinity period (Figure 4). Below 20 $\mathrm{cm}$ of depth, a large increase in the AVS content $(>200$ $\mathrm{mg} \mathrm{kg}^{-1}$ ) was observed in the maximum salinity period (Figure 4) whereas freshwater period concentrations in the same section of the profile were lower and relatively stable (up to $93 \mathrm{mg} \mathrm{kg}^{-1}$ ).

The CRS showed mean concentrations much higher in the freshwater period $(1948.77 \pm 1428.99 \mathrm{mg}$ $\mathrm{kg}^{-1}$ ) in comparison to the maximum salinity period (715.26 $\pm 210.31 \mathrm{mg} \mathrm{kg}^{-1}$; Table 2). However, in the first $5 \mathrm{~cm}$ of the core, the variation in concentrations was minimal, presenting CRS concentrations slightly higher in the maximum salinity period (Figure 4). For the interval of 5-30 cm, a large enrichment of CRS was observed in the freshwater period, with concentrations higher than $3500 \mathrm{mg} \mathrm{kg}^{-1}$ and with remarkable oscillatory distribution (Figure 4). On the other hand, the CRS concentration did not exceed $1126.06 \mathrm{mg} \mathrm{kg}^{-1}$ for the same interval in the maximum salinity period, showing relatively constant distribution (Figure 4). In fact, between $5-30 \mathrm{~cm}$ depth, the CRS levels were about four times lower in the maximum salinity period than in the freshwater period (Figure 4). The CRS contents corresponded 

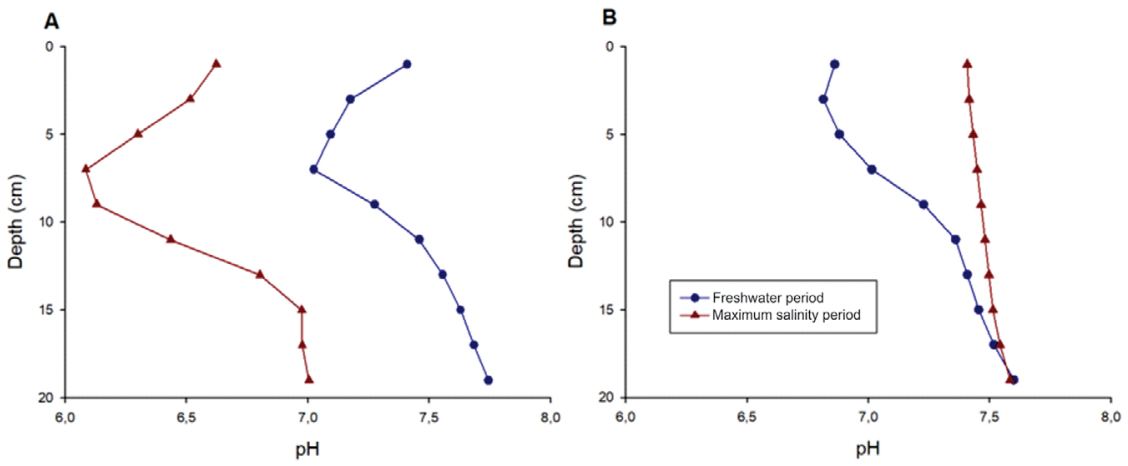

Figure 3. Vertical distribution $(0-20 \mathrm{~cm})$ of $\mathrm{pH}$ in $\mathrm{SM}(\mathrm{A})$ and $\mathrm{NV}(\mathrm{B})$ sites.
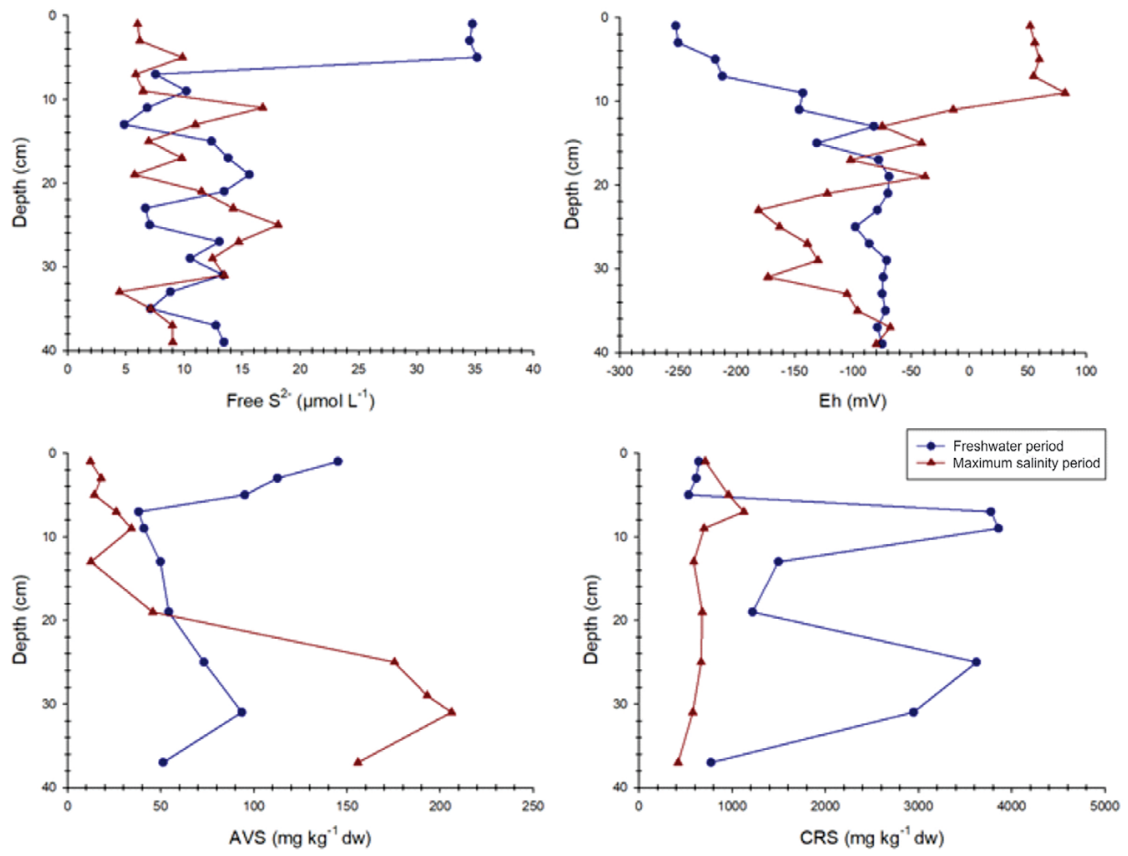

Figure 4. Sulfides distribution (Free-S2-; AVS and CRS) and redox potential (Eh) as a function of depth from the SM site in Pólvora Island salt marsh.

to around $93 \%$ of the TRIS pool in the freshwater period, while this value decreased to near $83 \%$ in the maximum salinity period.

Vertical distribution and temporal VARIATION OF EH AND SULFIDES IN THE NON-VEGETATED ZONE SEDIMENTS

The overall mean percentages of Eh were similar for both sampling periods (Table 3), with a mean of $-134.7 \pm 91.3 \mathrm{mV}$ for the freshwater period and -139.9 $\pm 71.52 \mathrm{mV}$ for the maximum salinity period. In both periods, the redox potential for sediments from the NV site presented a decreasing tendency with depth; reaching values lower than $-250 \mathrm{mV}$ in the last centimeters of the profiles (Figure 5).

The highest concentrations for the free sulfides, AVS, and CRS were observed in sediments from the freshwater period, where these parameters attain values of $387.87 \mu \mathrm{mol} \mathrm{L}^{-1}, 299.65 \mathrm{mg} \mathrm{kg}^{-1}$, and 4554.79 $\mathrm{mg} \mathrm{kg}{ }^{-1}$, respectively (Table 3). Some patterns deserve attention when considering the vertical distribution of these variables. For example, between $10-25 \mathrm{~cm}$ higher Free- $\mathrm{S}^{2-}$ levels were noticed in the maximum salinity period, probably due to a more intense sulfate reduction process, which reflects a lower Eh in this same interval for this period. 

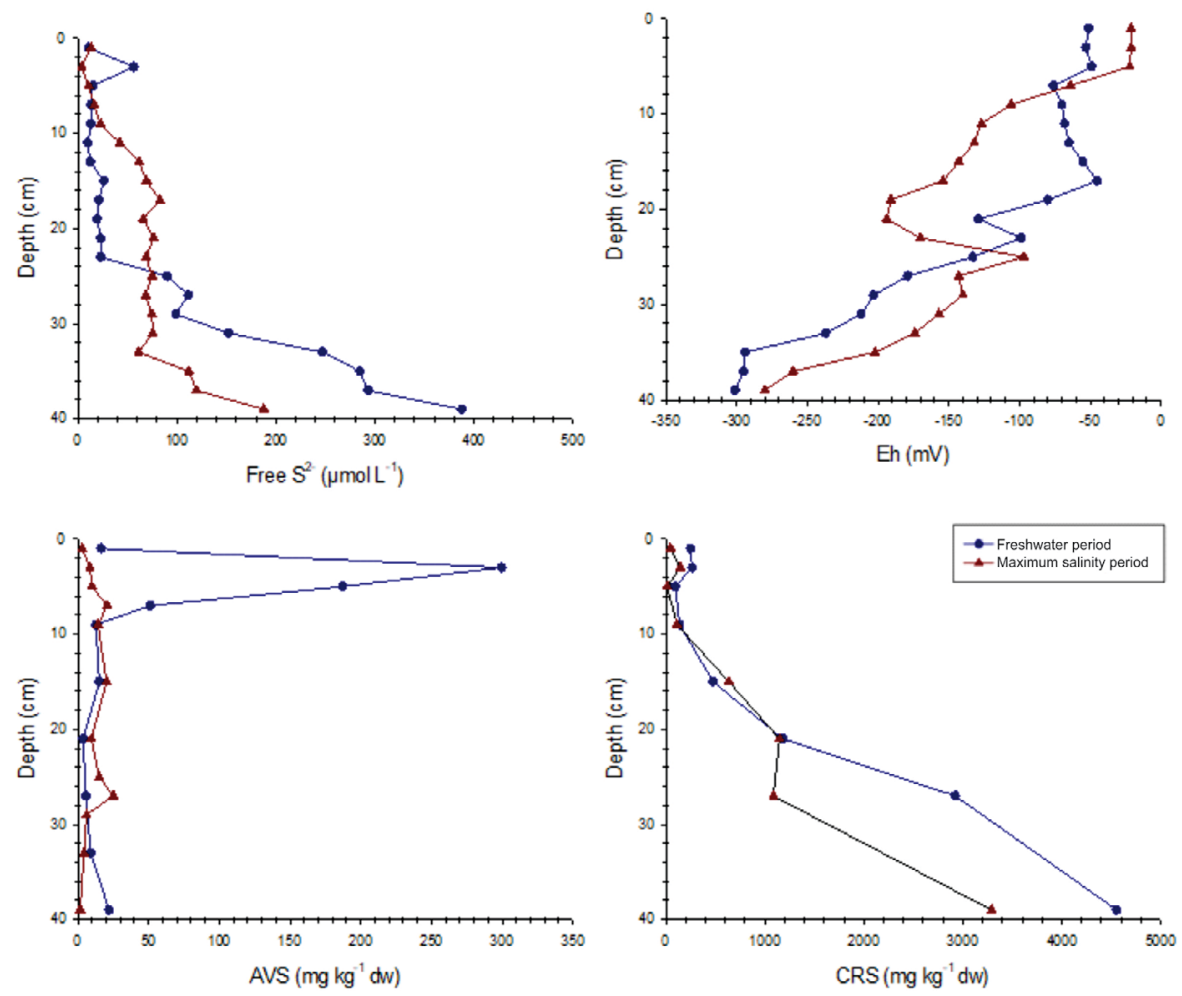

Figure 5. Sulfides distribution (Free- $\mathrm{S}^{2} ; \mathrm{AVS}$ and CRS) and redox potential (Eh) as a function of depth from the NV site.

In the lowest layer $(25-40 \mathrm{~cm})$ Free- $\mathrm{S}^{2-}$ showed a large increase with depth, which was $60 \mu \mathrm{mol} \mathrm{L^{-1 }}$ of magnitude for every $2 \mathrm{~cm}$ in the freshwater period. Similar conditions were observed in depths higher than $30 \mathrm{~cm}$ during the maximum salinity period (Figure 5).

The AVS distribution was distinct between the two hydrological regimes in the uppermost portion of the profiles for the NV site (Figure 5). There was a significant decrease in AVS content in the interval of $0-10 \mathrm{~cm}$ between the freshwater ( $\left.>100 \mathrm{mg} \mathrm{kg}^{-1}\right)$ and maximum salinity (< $20 \mathrm{mg} \mathrm{kg}^{-1}$ ) periods. From 10 to $40 \mathrm{~cm}$, no variations were observed with AVS average concentrations of $11 \pm 8 \mathrm{mg}$ $\mathrm{kg}^{-1}$ in both periods (Figure 5).

The CRS concentrations showed a similar pattern of distribution during the two periods, with low concentrations in the uppermost layers and a large increase with depth. Considering the freshwater period, the CRS concentrations were lower than those of the AVS in the uppermost layers for the NV profile. In fact, in the $0-5 \mathrm{~cm}$ interval, the CRS corresponded to about $40 \%$ and $60 \%$ of the TRIS pool during the freshwater and maximum salinity periods, respectively. In deeper layers, a large CRS accumulation was observed in both periods with values higher than $3000 \mathrm{mg} \mathrm{kg}^{-1}$ (Figure 5). On average, the CRS content in NV sediments corresponded to approximately $83 \%$ and $91 \%$ of TRIS for the freshwater and maximum salinity periods, respectively.

\section{DISCUSSION}

\section{Organic matter contribution to sulfate Reduction IN ESTUARINE SEDIMENTS}

The OC vertical distribution was significantly distinct between the two sampling sites (Figure 2). The main source of organic matter in uppermost salt marsh sediments consists of the local vegetation itself. In shallow estuarine non-vegetated zones, $\mathrm{OC}$ tends to be from different sources, such as by river discharge and primary productivity in the water column (Huerta-Diaz and Reimer, 2010). The OC decline with depth at the SM core is probably a direct reflection of post-burial processes (Figure 2). On the other hand, OC contents in NV core were lower 
in comparison to those found in SM (Figure 2; Table 1), most likely due to the absence of vegetation and animals. Vertical distribution of $O C$ and fine grain at NV core presented a downward increase trend (Figure 2$)$ and a correlation ( $r=0.835 ; n=10$; Table 4$)$, indicating the grain size effect over $\mathrm{OC}$ distribution (Rojas and Silva, 2005; Li et al., 2016). However, an increase in the OC levels with depth may also indicate the presence of refractory organic matter (ÁlvarezIglesias and Rubio, 2012).

Silt and clay size particles have larger specific surface areas in comparison to sandy sediments because the area/volume ratio of fine grain sediments is much larger than that of these coarser grain materials (Rojas and Silva, 2005; Álvarez-Iglesias and Rubio, 2012). The surfaces of fine grain sediment tend to be coated by a layer of organic material (Winfrey, 1988). Hence, fine grained sediments (i.e., silt and clay size) commonly have larger contents of associated organic matter than coarser grained sediments like sands (Winfrey, 1988; Rojas and Silva, 2005; Álvarez-Iglesias and Rubio, 2012; Quintana et. al, 2020). The organic coating of such fine sediments is an important substrate for bacterial activity, stimulating oxygen and sulfate consumption, favoring the decrease of the redox potential, and enhancing the production of dissolved sulfide (Berner, 1970; Jørgensen and Kasten, 2005; Bianchi, 2007).

The relatively low OC levels at NV did not appear to be a limiting factor for sulfate reduction, which is indicated by the high levels of free and insoluble forms of sulfides observed at this core. The significant correlation of $\mathrm{OC}$ with Eh indicated by Pearson coeficient $(r=-0.816 ; n=11)$, and Free- $S^{2-}(r=0.840$; $\mathrm{n}=11$ ) during the freshwater period (Table 4) and with $<63 \mu \mathrm{m}$ ( $r=0.835$ ) could be explain the by the increase of sulfate reduction rate as function of the fine sediment distribution (Figure 5). In the maximum salinity period at both sites, OC did not show an expressive correlation with any other parameter (Table 4 and 5). However, fine sediment distribution probably plays a major role in sulfate reduction and sulfide formation processes at NV even during the maximum salinity period.

\section{CONDUCTIVITY AND PH OF SUPERFICIAL PORE WATER}

The mean conductivity in SM pore water was lower than that found at NV, especially during the maximum salinity period (Table 2, 3), which is a probable consequence of the hypsometric level of these sampling points. The salt marsh from Pólvora Island can be eventually exposed to subaerial conditions during

Table 4. Pearson correlation coefficient values (significant correlations in bold for $p<0.01$, using TOC, Eh, Free-S²-, CRS, AVS and Fine Grain $(<63 \mu \mathrm{m})$ results from NV during the freshwater and maximum salinity periods.

\begin{tabular}{|c|c|c|c|c|c|c|}
\hline \multicolumn{7}{|c|}{ Freshwater Period } \\
\hline & TOC & $<63 \mu \mathrm{m}$ & Eh & Free-S ${ }^{2-}$ & CRS & AVS \\
\hline & $\mathrm{n}=11$ & $\mathrm{n}=10$ & $\mathrm{n}=20$ & $\mathrm{n}=20$ & $n=8$ & $n=10$ \\
\hline TOC & 1 & 0,835 & $-0,816$ & 0,927 & 0,794 & 0,105 \\
\hline$<63 \mu \mathrm{m}$ & & 1 & $-0,946$ & 0,903 & 0,975 & $-0,383$ \\
\hline Eh & & & 1 & $-0,940$ & $-0,985$ & 0,407 \\
\hline Free-S'- & & & & 1 & 0,918 & $-0,206$ \\
\hline CRS & & & & & 1 & $-0,363$ \\
\hline AVS & & & & & & 1 \\
\hline \multicolumn{7}{|c|}{ Maximum salinity Period } \\
\hline & TOC & $<63 \mu \mathrm{m}$ & Eh & Free-S ${ }^{2-}$ & CRS & AVS \\
\hline & $\mathrm{n}=11$ & $\mathrm{n}=10$ & $\mathrm{n}=20$ & $\mathrm{n}=20$ & $\mathrm{n}=8$ & $\mathrm{n}=12$ \\
\hline TOC & 1 & 0,835 & $-0,567$ & 0,680 & 0,823 & $-0,593$ \\
\hline$<63 \mu \mathrm{m}$ & & 1 & $-0,608$ & 0,827 & 0,930 & $-0,389$ \\
\hline Eh & & & 1 & $-0,901$ & $-0,877$ & 0,143 \\
\hline Free- $\mathrm{S}^{2-}$ & & & & 1 & 0,984 & $-0,238$ \\
\hline CRS & & & & & 1 & $-0,248$ \\
\hline AVS & & & & & & 1 \\
\hline
\end{tabular}


Table 5. Pearson correlation coefficient values (significant correlations in bold for $p<0.01$ ), using TOC, Eh, Free- $S^{2-}$, CRS, AVS and Fine Grain $(<63 \mu \mathrm{m})$ results from SM during the freshwater and maximum salinity periods.

\begin{tabular}{|c|c|c|c|c|c|c|}
\hline \multicolumn{7}{|c|}{ Freshwater Period } \\
\hline & TOC & $<63 \mu \mathrm{m}$ & Eh & Free-S ${ }^{2-}$ & CRS & AVS \\
\hline & $(n=11)$ & $\mathrm{n}=10$ & $\mathrm{n}=20$ & $n=20$ & $\mathrm{n}=10$ & $\mathrm{n}=11$ \\
\hline TOC & 1 & $-0,632$ & $-0,922$ & 0,840 & $-0,443$ & 0,803 \\
\hline$<63 \mu \mathrm{m}$ & & 1 & 0,473 & $-0,578$ & 0,647 & $-0,512$ \\
\hline Eh & & & 1 & $-0,718$ & 0,254 & $-0,642$ \\
\hline Free-S ${ }^{2-}$ & & & & 1 & $-0,703$ & 0,857 \\
\hline CRS & & & & & 1 & $-0,513$ \\
\hline AVS & & & & & & 1 \\
\hline \multicolumn{7}{|c|}{ Maximum salinity Period } \\
\hline & TOC & $<63 \mu \mathrm{m}$ & Eh & Free-S ${ }^{2-}$ & CRS & AVS \\
\hline & $\mathrm{n}=11$ & $n=10$ & $n=20$ & $\mathrm{n}=20$ & $\mathrm{n}=9$ & $\mathrm{n}=11$ \\
\hline TOC & 1 & $-0,632$ & 0,216 & $-0,522$ & 0,404 & $-0,619$ \\
\hline$<63 \mu \mathrm{m}$ & & 1 & $-0,202$ & 0,562 & 0,067 & 0,282 \\
\hline Eh & & & 1 & $-0,583$ & 0,596 & $-0,608$ \\
\hline Free-S2- & & & & 1 & $-0,312$ & 0,731 \\
\hline CRS & & & & & 1 & $-0,537$ \\
\hline AVS & & & & & & 1 \\
\hline
\end{tabular}

the maximum salinity periods (i.e., dry season) since it is located on an intertidal mudflat $15-25 \mathrm{~cm}$ below the mean water level of Patos Estuary, hampering the continuous diffusion of water to the sediments (Mirlean and Costa, 2017). The salt marsh superficial sediment can also be exposed to rainwater during subaerial exposure periods, contributing to the lower conductivity found in this sampling point since the mean atmospheric precipitation in Rio Grande during March 2017 (i.e., the month before sampling) was $169.2 \mathrm{~mm}$, higher than the annual mean for the same year (i.e., $91.93 \mathrm{~mm}$ ), according to the center of meteorological studies from Federal University of Rio Grande.

The $\mathrm{pH}$ vertical distribution in superficial pore water was similar in SM during both sampling periods (Figure 3), presenting a remarkable decrease in the first $15 \mathrm{~cm}$ of the profile. However, the mean $\mathrm{pH}$ values were lower during the maximum salinity period (Table 2; Figure 3) for SM location. The acidification of superficial pore waters from Pólvora Island was previously related to the oxidation of iron sulfides due to the combined effect of oxygenenriched underlaying water diffusion to sediment, biological disturbances and/or eventual exposure to subaerial conditions, releasing dissolved sulfides to pore water and enabling the subsequent formation of sulfuric acid (Mirlean and Costa, 2017). Similar acidification was described for salt marsh sediments as a consequence of the oxidation of both iron sulfides and amines, enabling the formation of sulfuric and nitric acids, respectively (Liu et al., 2008). Such processes are probably accountable for the acidification of superficial pore waters at SM, especially during the maximum salinity period associated to formation of carbonic acid as a byproduct of organic matter oxidation (Figure 3 ).

The conductivity of pore water from NV directly reflected the irregular regime of Patos Estuary, since the values from this sampling point were much higher during the maximum salinity period (Table 3). Strong $\mathrm{pH}$ variations of pore water occurred in the first 20 $\mathrm{cm}$ depth of the profile. During the freshwater period, the $\mathrm{pH}$ of superficial pore water was lower than that found during the maximum salinity period (Figure 3). This was a probable consequence of alkaline marine water diffusion to the sediments during the maximum salinity period and, in contrast, the diffusion of freshwater of continental origin led to a decrease of the $\mathrm{pH}$ of superficial pore water during the freshwater period. 
THE HYDROLOGICAL REGIME AND BIOIRRIGATION AS MAIN DRIVERS OF SULFIDES DISTRIBUTION IN SM SEDIMENT

Evidence of intense sulfate reduction accompanied by an important decline in the redox potential in the uppermost layers of SM sediments was found during the high-water level and low salinity phase (Figure 4). We hypothesize that the high content of organic matter at SM (Figure 2), together with the presence of less oxidizing conditions in the salt marsh sediments induce an intense sulfate reduction process. As a result, a high AVS concentration in the first $10 \mathrm{~cm}$ of the profile during the freshwater period was observed (Figure 4). The freshwater environment at the Patos Lagoon estuary is formed during austral winter and spring, i.e. when the salt marsh vegetation shows minimal growth and a great contribution of vegetal debris to the sediments happens (Peixoto and Costa, 2004). This leads to an increase in oxygen consumption in the uppermost sedimentary layers at SM, leading to a decrease in the redox potential at the top of the SM profile (Figure 4).

During the period of low-water level and maximum salinity, oxidizing conditions are predominant in the uppermost SM sediments, which significantly decreases the AVS levels (Figure 4). This re-oxidation of sulfides (Free $\mathrm{S}^{-2}, \mathrm{AVS}$, and CRS) and decrease of sulfate reduction in the superficial sedimentary layers of salt marshes within Patos Lagoon estuary were previously related to the occasional sediment exposure to aerial conditions due to the hypsometric levels at such locations (Mirlean and Costa, 2017). SM site is located in a higher ground (15 - $25 \mathrm{~cm}$ below the mean water level of the estuary) in comparison to NV $(100-150 \mathrm{~cm}$ below the mean water level). Therefore, its superficial sediments can be eventually exposed to subaerial conditions during the maximum salinity periods, when the water level is low, contributing to Eh increase and a subsequent decrease of sulfide contents in superficial sediment layers (Figure 4).

Water level variations were already claimed to be an important factor by inducing temporal variation on the redox zonation in salt marshes (Feijtel et al., 1988; Oenema, 1990; Xin et al., 2013). For a microtidal estuary ( $0.5 \mathrm{~m}$ of tidal range), as it is the case with the Patos Lagoon estuary, tides are an almost negligible factor for local hydrodynamics (Barros et al., 2014). Water level variations in this estuary are mainly controlled by the wind and river discharge (Vaz et al., 2006; Möller et al., 2009; Barros et al., 2014). The changes in water levels lead to irregular flooding in the salt marshes within the estuary (Costa et al., 2003; Mirlean and Costa, 2017) and contribute to a significant temporal variation (up to 3-4 months) in the redox conditions, as indicated here by the SM redox potential profile (Figure 4). For the freshwater period, despite the highly reducing conditions on the surface, the Eh values indicated sub-oxic conditions below $20 \mathrm{~cm}$ of depth at the SM site (Figure 4). In the maximum salinity period, oxidizing conditions were identified in the uppermost sedimentary layers. However, in the $20-25 \mathrm{~cm}$ interval, more reducing conditions than in the freshwater period were observed (Figure 4). This suggests that the oxygen penetration into deeper layers of SM sediments is not constant and probably happens through different pathways that are independent of the hydrological regime (i.e., pumping by the plants' roots, penetration through crab channels, etc.).

It is estimated that 7000 ha of the southern Patos Lagoon estuary are occupied by salt marshes where $S$. alterniflora and S. densiflora constitute the dominant native vegetation. The burrowing crab (Neohelice granulata) is the main animal species that lives in the salt marshes from the SM site (Costa et al., 2003). The activities of these crustaceans promote significant alterations in the physicochemical aspects of the sediments (Costa et al., 2019). These animals can excavate semi-permanent vertical tunnels of about 10 $\mathrm{cm}$ diameter and $1 \mathrm{~m}$ depth (Angeletti and Cervellini, 2015), removing and redistributing considerable amounts of sediment (Iribarne et al., 2000). Previous studies in salt marshes from southwestern Atlantic revealed that Neohelice Granulata population density varies from 15 to 77 individuals per $\mathrm{m}^{2}$ (Alberti et al., 2007; Martinetto et al., 2016).

The redox oscillations in the highly disturbed sediment profile of the SM site influenced the distribution of the different forms of sulfides (Table 5). However, below $10 \mathrm{~cm}$ depth, ANOVA analysis demonstrated that AVS, CRS, and Free- $\mathrm{S}^{-2}$ mean concentrations were not significantly different during both sampling periods (Table 6). Despite the much larger organic load at SM (Table 1), the average Free-S2- levels in the pore water were much lower than those found in the NV sediment profile, even during the freshwater period (Table 2, 3). The formation of insoluble iron sulfides tends to be the main process accountable for the removal of free sulfides from 
Table 6. ANOVA analysis and Fisher LSD post hoc test $(\mathrm{n}=$ $10 ; p<0.05)$ using Eh, Free-S2-, CRS and AVS results from SM sediments (below $10 \mathrm{~cm}$ depth) during the freshwater (FWP) and the maximum salinity periods (MSP).

\begin{tabular}{cl}
\hline AVS & FWP $=$ MSP \\
CRS & FWP $>$ MSP \\
Free-S ${ }^{2-}$ & FWP $=$ MSP \\
Eh & FWP $=$ MSP \\
\hline
\end{tabular}

solution (Panutrakul et al., 2001). However, these low Free-S2- contents at SM sediments probably are caused by re-oxidizing processes induced by bioturbation (Ferreira, 2010). The biological disturbances caused by native vegetation roots and burrow crabs are capable of facilitating the penetration of oxygen up to $25-35 \mathrm{~cm}$ depth in the sediment column of the salt marshes from Patos Lagoon estuary (Costa et al., 2017; Costa et al., 2019). Such oxidizing conditions could affect the sulfate reduction process, hampering the formation of sulfides.

A previous study has demonstrated that vegetation roots in salt marshes can catalyze sulfide oxidation at depth by pumping oxygen to the rhizosphere (Lee, 1999). Costa et al. (2017) has already reported that the $\mathrm{O}_{2}$ penetration into deeper sedimentary zones via vegetation roots and crab channels exert a strong influence on geochemical processes in this same salt marsh. Our data suggested that re-oxidation processes induced by both bioturbation and eventual exposure to subaerial conditions possibly contributed to the low levels of free sulfides observed at SM sediments. The varied disturbances in SM sediments may have also favored the $\mathrm{H}_{2} \mathrm{~S}$ loss to the atmosphere, which is another important destination for free sulfides in salt marshes (Luther et al., 1991).

ANOVA analysis may show that the sum of the influence exerted by bioturbation/bioirrigation and the irregular flooding dynamics in this salt marsh significantly affected the CRS distribution in deeper layers during both sampling periods (Table 6). Below $20 \mathrm{~cm}$ of depth, CRS levels are strongly reduced between the freshwater and maximum salinity periods whereas the AVS levels showed a large increase (Figure 4). Theoretically, if we assigned the decrease in CRS levels to re-oxidation processes, the same should happen to AVS and in a more intense way, because AVS concentrations in sediments tend to be strongly controlled by the redox potential. The establishment of oxidizing conditions in a layer containing AVS will tend to rapidly re-oxidize these metastable sulfides to sulfate. Therefore, what is expected here is a strong depletion in AVS levels between the two hydrological regimes. That can be noticed in the uppermost layers of the profile $(0-5 \mathrm{~cm})$. However, in deeper layers $(20-40 \mathrm{~cm})$, AVS contents increase (Figure 4).

This peculiar pattern in the distribution of different sulfide forms can be explained by the oscillatory redox nature of this environment and by the AVS highly reactive nature. As previously discussed, the bioturbation and irregular flooding processes in SM may induce strong redox variation in the sediments in short periods. In persistent oxidizing conditions (i.e., during subaerial exposition), the AVS and partial CRS oxidation could initially lead to a large decrease in the concentration of these sulfides in the sediments, with AVS practically disappearing. However, although the oxidative destruction of AVS happens faster than that of CRS during the subaerial exposition, the AVS formation also comes about more rapidly under anaerobic conditions that tend to be caused by the submersion of SM sediments during flooding events (Rickard and Morse, 2005).

\section{HYDRO-CHEMICAL VARIATIONS IN ESTUARINE WATERS AND DISTRIBUTION OF SULFIDES AT THE NON-VEGETATE ZONE}

For the NV site, the Eh distribution in the uppermost layers showed a slight variation between the two periods (Figure 5), presenting milder reducing conditions during the maximum salinity period (Table 3). At greater depths, however, ANOVA analysis indicated no significant differences for Eh mean values between both sampling periods (Table 7). The NV sediments are practically undisturbed with feebly-marked bioturbation processes. The influence of oxidizing water diffusion during maximum salinity period appears to be restricted to the first centimeters of the sedimentary column. With the increase in depth, the Eh distribution indicated the establishment of increasingly reducing conditions (<-250mV; Figure 5), characteristic of sulfidic media (Mansfeldt, 2004; Du Laing et al., 2009).

A significant anti-correlation between Eh and Free-S2- $(r=-0.94$ during freshwater period; $r=-0.90$ in maximum salinity period; $n=20)$ and with $C R S(r=-0.99$ 
Table 7. ANOVA analysis and Fisher LSD post hoc test $(\mathrm{n}=8 ; p<0.05)$ using Eh, Free- $\mathrm{S}^{2-}, \mathrm{CRS}$ and AVS results from NV sediments (below $10 \mathrm{~cm}$ depth) during the freshwater (FWP) and the maximum salinity periods (MSP).

\begin{tabular}{cl}
\hline AVS & FWP $=$ MSP \\
CRS & FWP $=$ MSP \\
Free-S ${ }^{2-}$ & FWP $=$ MSP \\
Eh & FWP $=$ MSP \\
\hline
\end{tabular}

during freshwater period; $r=-0.88$ during maximum salinity period; $\mathrm{n}=8$ ) can be observed, as well as between CRS and Free- $S^{2}(r=0.92$ during freshwater period; $r=0.98$ during maximum salinity period; $n=$ 8) in both sampling periods (Table 4). During early diagenesis, free sulfides will tend to undergo three major processes: oxidation, precipitation of metallic sulfides, and formation of organic compounds (Vairavamurthy et al., 1995). For layers below $10 \mathrm{~cm}$ of depth (free from the influence of water diffusion), our data suggest that the distribution of free sulfides at the NV core is mainly controlled by pyrite formation, furthermore ANOVA analysis indicated no significant variations between both sampling periods (Table 7). The Free-S2- and CRS accumulation with depth, as well as the low AVS levels, suggest that the pyrite is formed by the $\mathrm{H}_{2} \mathrm{~S}$ mechanism, in which $\mathrm{H}_{2} \mathrm{~S}$ directly reacts with iron (II) monosulfide to form pyrite under reducing conditions (Rickard and Luther, 1997, 2007; Rickard and Morse, 2005). This conversion from AVS into CRS probably contributes to the low AVS levels noticed below $10 \mathrm{~cm}$ of depth in the sediment cores at NV. The high Free- $\mathrm{S}^{2-}$ concentrations for the same interval $(<10 \mathrm{~cm})$ may be indicating low availability of reactive iron to react with and remove Free- $S^{2-}$ from solution. This process would also explain the low AVS concentrations in these deeper layers and would indicate that the CRS is the product of accumulation over time.

In the uppermost layers $(0-10 \mathrm{~cm})$ of the NV profile, the distribution of AVS and CRS suggests that the long-term hydrochemical variations in the estuarine waters control the distribution of these sulfides in each sampling period (Figure 5). During the freshwater period, the first $10 \mathrm{~cm}$ of the sedimentary pile showed anomalous AVS concentration, where AVS is much higher than CRS. This indicates that the redox conditions that prevailed in the sediments of this period favored the preservation of metastable forms of sulfides. The AVS concentration in sediments is determined both by the rate at which AVS is produced and the rate at which it is lost through oxidation or conversion into pyrite (Rickard and Morse, 2005).

In general, CRS tends to predominate over AVS with some exceptions. For example, high sedimentation rates and a temperature increase favor the accumulation of metastable sulfides by inducing persistent reducing conditions over time (Oenema, 1990). Gagnon et al. (1995) demonstrated that elevated reactive iron concentrations and high sulfate reduction rates facilitate an accumulation of AVS over pyrite. These authors argue that the conversion of AVS into pyrite tends to be slow and depends on the presence of oxidant agents (mainly $\mathrm{H}_{2} \mathrm{~S}$ ) that lead to the formation of intermediate byproducts, such as elemental sulfur and polysulfides, where the conversion of AVS into pyrite subsequently takes place. This process of formation of pyrite from AVS with $\mathrm{H}_{2} \mathrm{~S}$ serving as an oxidant agent concerning FeS under reducing conditions is also referred to as the polysulfide mechanism (Rickard and Morse, 2005; Rickard and Luther, 2007). If those AVS oxidative processes are slow or nonexistent, then AVS tends to accumulate and can reach anomalous concentrations (Gagnon et al., 1995; Rickard and Morse, 2005). This process is probably accountable for the AVS increase in the $0-10 \mathrm{~cm}$ interval at NV site during the freshwater period when the Eh of this sedimentary layer was more reducing in comparison to the maximum salinity period (Figure 5).

The diffusions of water less enriched in oxygen into the sediments during the freshwater period (Windom et al., 1999) probably favor a greater persistence of reducing conditions overtime, facilitating the AVS preservation in sediments from superficial layers at NV site. AVS accumulation in uppermost sedimentary layers suggests that there was not enough time for the conversion from AVS to CRS through the polysulfide mechanism since this process is slow (Gagnon et al., 1995). However, below $10 \mathrm{~cm}$ depth, AVS concentration was low and similar during both sampling periods (Table 7), most probably due to the conversion from $\mathrm{FeS}$ to pyrite with $\mathrm{H}_{2} \mathrm{~S}$ serving as oxidant agent of $\mathrm{FeS}$ under persistent reducing conditions.

Lower $\mathrm{O}_{2}$ levels in the overlying water imply a lower availability of this electron acceptor in the sediments and, hence, the $\mathrm{O}_{2}$ diffusion tends to be confined to 
the first millimeters of the sedimentary pile. With the intrusion of more oxic saltwater, higher $\mathrm{O}_{2}$ availability in the overlying water led to a deepening of the oxic layer. Consequently, during the maximum salinity period, AVS was re-oxidized and this resulted in its low levels observed in the uppermost sediment (Figure 5). This hypothesis of AVS oxidation due to DO increase in the overlying water has already been suggested by Hernández-Crespo and Martín (2013). CRS also showed a slight decrease in its levels from the freshwater to the maximum salinity period in NV core uppermost layers. This indicates that the redox conditions that prevailed in the uppermost sediment during the maximum salinity period prevented the accumulation and the conversion of AVS into pyrite and even allowed the oxidation of a CRS portion that was present in the freshwater period (Figure 5).

\section{CONCLUSIONS}

In sediments of an estuary with a strong irregular hydrological regime, TRIS concentrations increased during the freshwater period and decreased during the maximum salinity period. The most significant seasonal variations for Eh and sulfides were noticed in the uppermost sediments. The most reactive forms of sulfides (i.e. Free-S2- and AVS) have shown the greatest temporal variation between the two hydrological regimes. In the non-vegetated area, AVS represented the predominant form in the TRIS pool within the uppermost $5 \mathrm{~cm}$ of the sediment core during the freshwater period, which drastically decreased for the maximum salinity period. In the salt marsh, temporal variations in the distribution of sulfides were also observed. There, the decrease in the mean water level of the estuary during the maximum salinity period led to the oxidation of most AVS present in the uppermost layers $(0-10 \mathrm{~cm})$. In the non-vegetated zone, the ANOVA analysis allowed us to presume that no significant seasonal variations occurred in deeper sedimentary layers (below 10 $\mathrm{cm})$. However, considering the same interval $(<10$ $\mathrm{cm}$ depth) for salt marsh sediments, CRS contents were higher during the freshwater period in contrast to those found in the maximum salinity period. High Free-S2- concentrations in the lower part of the sediment core in the non-vegetated area indicated elevated rates of sulfate reduction and/or reduced availability of reactive iron. In the salt marsh, bioturbation/bioirrigation processes contributed in controlling the temporal variation of AVS and CRS distribution. The high degree of disturbance in the sediments probably contributed to the low Free-S2concentrations in the salt marsh.

\section{ACKNOWLEDGMENTS}

The research was funded by Conselho Nacional de Desenvolvimento Científico e Tecnológico (CNPq) through grant 303848/2013-8. The authors are grateful for anonymous reviewers for their valuable comments which served for significant improvement of the article.

\section{AUTHOR CONTRIBUTIONS}

N.M.: Conceptualization, Funding Acquisition, Investigation, Methodology, Project administration, Supervision

A.B.:: Writing-original draft, Investigation, Formal analysis

G.Q.: Writing review \& editing, Formal analysis, Investigation

L.P.: Writing review \& editing, Investigation

A.F.: Writing review \& editing, Investigation

\section{REFERENCES}

ABNT (Associação Brasileira de Normas Técinicas) 1987. Determinação da composição granulométrica - NBR 7217, Rio de Janeiro: ABNT.

ALBERTI, J., ESCAPA, M. \& DALEO. P. 2007. Local and geographic variation in grazing intensity by herbivorous crabs in SW Atlantic salt marshes. Marine Ecology Progress Series, 349, 235-243.

ÁLVAREZ-IGLESIAS, P. \& RUBIO, B. 2012. Early diagenesis of organic-matter-rich sediments in a ría environment: Organic matter sources, pyrites morphology and limitation of pyritization at depth. Estuarine, Coastal and Shelf Science, $100,113-123$.

ANGELETTI, S. \& CERVELLINI, P. 2015. Estructura poblacional del cangrejo cavador Neohelice granulata (Brachyura, Varunidae) en una marisma del Atlántico sudoccidental. Latin American Journal of Aquatic Research, 43, 539-547.

ANTIQUEIRA, J. \& CALLIARI, L. 2005. Características sedimentares da desembocadura da Laguna dos Patos. Gravel, 3, 39-46.

BARROS, G., MARQUES, W. \& KIRINUS, E. 2014. Influence of the freshwater discharge on the hydrodynamics of Patos Lagoon, Brazil. International Journal of Geosciences, 5, 925-942.

BERNER, R. 1970. Sedimentary pyrite formation. American Journal of Science, 268, 1-23.

BIANCHI, T. 2007. Biogeochemistry of Estuaries. Oxford: Oxford University Press. 
BROOKS, K. 2001. An evaluation of the relationship between salmon farm biomass, organic inputs to sediments, physicochemical changes associated with those inputs and the infaunal response. Aquatic Environmental Sciences, 1-173.

BRÜCHERT, V., JØRGENSEN, B., NEUMANN, K., RIECHMANN, D., SCHLÖSSER, M. \& SCHULZ, H. 2003. Regulation of bacterial sulfate reduction and hydrogen sulfide fluxes in the central namibian coastal upwelling zone. Geochimica et Cosmochimica Acta, 67, 4505-4518.

COSTA, C., MARANGONI, J. \& AZEVEDO, A. 2003. Plant zonation in irregularly flooded salt marshes: relative importance of stress tolerance and biological interactions. Journal of Ecology, 91, 951-965.

COSTA, L., MIRLEAN, N. \& GARCIA, F. 2017. Arsenic Environmental Threshold Surpass in Estuarine Sediments: Effects of Bioturbation. Bulletin of Environmental Contamination and Toxicology, 98, 521-524.

COSTA, L., MIRLEAN, N. \& QUINTANA, G. 2019. Distribution and Geochemistry of Arsenic in Sediments of the World 's Largest Choked Estuary: the Patos Lagoon , Brazil. Estuaries and Coasts, 42, 1896-1911.

DU LAING, G., RINKLEBE, J., VANDECASTEELE, B., MEERS, E. \& TACK, F. 2009. Trace metal behaviour in estuarine and riverine floodplain soils and sediments: A review. Science of The Total Environment, 407, 3972-3985.

FEIJTEL, T., DELAUNE, R. \& PATRICK, W. 1988. Seasonal Pore Water Dynamics in Marshes of Barataria Basin, Louisiana. Soil Science Society of America Journal, 52, 59-67.

FERREIRA, T. 2010. Bioturbation and its role in iron and sulfur geochemistry in mangrove soils. In: PÉREZ, X. \& VAZQUEZ, F. (eds) Biogeochemistry and Pedogenetic Process in Saltmarsh and Mangrove Systems. New York: Nova Science Publishers.

FOSSING, H. \& JØRGENSEN, B. 1989. Measurement of bacterial sulfate reduction in sediments: Evaluation of a single-step chromium reduction method. Biogeochemistry, 8, 205-222.

GAGNON, C., MUCCI, A. \& PELLETIER, É. 1995. Anomalous accumulation of acid-volatile sulphides (AVS) in a coastal marine sediment, Saguenay Fjord, Canada. Geochimica et Cosmochimica Acta, 59, 2663-2675.

HERNÁNDEZ-CRESPO, C. \& MARTÍN, M. 2013. Mid-Term Variation of Vertical Distribution of Acid Volatile Sulphide and Simultaneously Extracted Metals in Sediment Cores From Lake Albufera (Valencia, Spain). Archives of Environmental Contamination and Toxicology, 65, 654-664.

HUERTA-DIAZ, M. \& REIMER, J. (2010) Biogeochemistry of Sediments. In: PÉREZ, X. \& VAZQUEZ F. (eds) Biogeochemistry and Pedogenetic Process in Saltmarsh and Mangrove Systems, New York: Nova Science Publishers.

HYUN, J., SMITH, A. \& KOSTKA, J. 2007. Relative contributions of sulfate- and iron(III) reduction to organic matter mineralization and process controls in contrasting habitats of the Georgia saltmarsh. Applied Geochemistry, 22, 2637-2651.

IRIBARNE, O., BOTTO, F., MARTINETTO, P. \& GUTIERREZ, J. 2000. The role of burrows of the SW Atlantic intertidal crab Chasmagnathus granulata in trapping debris. Marine Pollution Bulletin, 40, 1057-1062.

IVANOFF, M., TOLDO, E., FIGUEIRA, R. \& FERREIRA, P. 2020. Use of ${ }^{210} \mathrm{~Pb}$ and ${ }^{137} \mathrm{Cs}$ in the assessment of recent sedimentation in Patos Lagoon, southern Brazil. Geo-Marine Letters.
JøRGENSEN, B. \& KASTEN, S. 2005. Sulfur Cycling and Methane Oxidation. In: SCHULZ, H. \& ZABEL, M. (eds) Marine Geochemistry, Berlin: Springer.

KJERFVE, B. 1994. Coastal lagoons. In: KJERFVE, B. (ed) Coastal Lagoon Processes, Amsterdam: Elsevier Oceanographic Series.

KORETSKY, C., CUELLAR, A., HAVEMAN, M., BEUVING, L., SHATTUCK, T. \& WAGNER, M. 2008. Influence of Spartina and Juncus on saltmarsh sediments. II. Trace element geochemistry. Chemical Geology, 255, 100-113.

KRISTENSEN, E., ANDERSEN, F. \& BLACKBURN, T. 1992. Effects of benthic macrofauna and temperature on degradation of macroalgal detritus: The fate of organic carbon. Limnology and Oceanography, 37, 1404-1419.

LEE, R., KRAUS, D. \& DOELLER, J. 1999. Oxidation of sulfide by Spartina alterniflora roots. Limnology and Oceanography, 44, 1155-1159.

LI, D., LIU, X., LIU, Z. \& ZHAO, X. 2016. Variations in total organic carbon and acid-volatile sulfide distribution in surface sediments from Luan River Estuary, China. Environmental Earth Sciences, 75, 1-11.

LIU, Z., LEE, C. \& ALLER, R. 2008. Drying effects on decomposition of salt marsh sediment and on lysine sorption. Journal of Marine Research, 66, 665-689.

LUTHER, G., FERDELMAN, T., KOSTKA, J., TSAMAKIS, E. \& CHURCH, T. 1991. Temporal and spatial variability of reduced sulfur species $\left(\mathrm{FeS}_{2}, \mathrm{~S}_{2} \mathrm{O}_{3}{ }^{2-}\right)$ and porewater parameters in salt marsh sediments. Biogeochemistry, 14, 57-88.

MANSFELDT, T. 2004. Redox potential of bulk soil and soil solution concentration of nitrate, manganese, iron, and sulfate in two Gleysols. Journal of Plant Nutrition and Soil Science, 167, 7-16.

MARQUES, W., FERNANDES, E., MORAES, B., MÖLLER, O. \& MALCHEREK, A. 2010. Dynamics of the Patos Lagoon coastal plume and its contribution to the deposition pattern of the southern Brazilian inner shelf. Journal of Geophysical Research, 115, 1-22.

MARTINETTO, P., MONTEMAYOR, D. \& ALBERTI, J. 2016. Crab bioturbation and herbivory may account for variability in carbon sequestration and stocks in south west atlantic salt marshes. Frontiers in Marine Science, 3,1-12.

MARVIN-DIPASQUALE, M. \& CAPONE, D. 1998. Benthic sulfate reduction along the Chesapeake Bay central channel. I. Spatial trends and controls. Marine Ecology Progress Series, $168,213-228$.

MARVIN-DIPASQUALE, M., BOYNTON, W. \& CAPONE, D. 2003. Benthic sulfate reduction along the Chesapeake Bay central channel. II. Temporal controls. Marine Ecology Progress Series, 260, 55-70.

MIRLEAN, N. \& COSTA, C. 2017. Geochemical factors promoting die-back gap formation in colonizing patches of Spartina densiflora in an irregularly flooded marsh. Estuarine, Coastal and Shelf Science, 189, 104-114.

MÖLLER, O., CASTELLO, J. \& VAZ, A. 2009. The effect of river discharge and winds on the interannual variability of the pink shrimp Farfantepenaeus paulensis production in Patos Lagoon. Estuaries and Coasts, 32, 787-796.

MÖLLER, O., LORENZZENTTI, J., STECH, J. \& MATA, M. 1996. The Patos Lagoon summertime circulation and dynamics. Continental Shelf Research, 16, 335-351. 
MORSE, J. \& CORNWELL, J. 1987. Analysis and distribution of iron sulfide minerals in recent anoxic marine sediments. Marine Chemistry, 22, 55-69.

OENEMA, O. 1990. Sulfate reduction in fine-grained sediments in the Eastern Scheldt, southwest Netherlands. Biogeochemistry, 9, 53-74.

OTERO, X., FERREIRA, T., HUERTA-DÍAZ, M., PARTITI, C., SOUZA, V., VIDAL-TORRADO, P.\& MACÍAS, F. 2009. Geochemistry of iron and manganese in soils and sediments of a mangrove system, Island of Pai Matos (Cananeia - SP, Brazil). Geoderma, 148, 318-335.

PANUTRAKUL, S., MONTENY, F. \& BAEYENS, W. 2001. Seasonal variations in sediment sulfur cycling in the Ballastplaat mudflat, Belgium. Estuaries, 24, 257-265.

PEIXOTO, A. \& COSTA C. 2004. Produção primária líquida aérea de Spartina densiflora Brong. (Poaceae) no estuário da laguna dos Patos, Rio Grande do Sul, Brasil. Iheringia, 59, 27-34.

QUINTANA, G., MIRLEAN, N., COSTA, L., \& JOHANNESSON, K. 2020. Mercury distributions in sediments of an estuary subject to anthropogenic hydrodynamic alterations (Patos Estuary, Southern Brazil). Environmental Monitoring and Assessment, 192(5). doi:10.1007/s10661-020-8232-3

RICKARD, D. \& LUTHER, G. 1997. Kinetics of pyrite formation by the $\mathrm{H}_{2} \mathrm{~S}$ oxidation of iron (II) monosulfide in aqueous solutions between 25 and $125^{\circ} \mathrm{C}$ : The mechanism. Geochimica et Cosmochimica Acta, 61, 135-147.

RICKARD, D. \& LUTHER, G. 2007. Chemistry of iron sulfides. Chemical reviews, 107, 514-562.

RICKARD, D. \& MORSE, J. W. 2005. Acid volatile sulfide (AVS). Marine chemistry, 97, 141-197.

ROJAS, N. \& SILVA, N. 2005. Early diagenesis and vertical distribution of organic carbon and total nitrogen in recent sediments from southern Chilean fjords (Boca del Guafo to Pulluche Channel). Investigaciones marinas, 33, 183-194.
STUMM, W. and MORGAN, J.J. (1996) Aquatic Chemistry. Chemical Equilibria and Rates in Natural Waters. New York: John Wiley \& Sons, Inc.

SUNDBY, B. 2006. Transient state diagenesis in continental margin muds. Marine Chemistry, 102, 2-12.

USEPA (United States Environmental Protection Agency) 1991. Draft analytical method for determination of acid volatile sulfide in sediment. Whashinton: USEPA.

VAIRAVAMURTHY, M. \& SCHOONEN, M. 1995. Geochemical transformations of sedimentary sulfur. Washington: American Chemical Society.

VAZ, A., MÖLLER, O. \& ALMEIDA., T. 2006. Análise quantitativa da descarga dos rios afluentes da Lagoa dos Patos. Atlântica, 28, 13-23.

WANG, C., LIN, D., WANG, P., AO, Y., HOU, J. \& ZHU, H. 2015. Seasonal and spatial variations of acid-volatile sulphide and simultaneously extracted metals in the Yangtze River Estuary. Chemistry and Ecology, 31, 466-477.

WINDOM, H., NIENCHESKI, L. \& SMITH, R. 1999. Biogeochemistry of nutrients and trace metals in the estuarine region of the Patos Lagoon (Brazil). Estuarine, Coastal and Shelf Science, 48, 113-123.

XIN, P., LI, L. \& BARRY, D. 2013. Tidal influence on soil conditions in an intertidal creek marsh system. Water Resources Research, 49, 137-150.

YANG, Y., ZHANG, L., CHEN, F., KANG, M., WU, S. \& LIU, J. 2013. Seasonal variation of acid volatile sulfide and simultaneously extracted metals in sediment cores from the Pearl River Estuary. Soil and Sediment Contamination: An International Journal, 23, 480-496.

ZHANG, L., LIAO, Q., HE, W., SHANG, J. \& FAN, C. 2013. The effects of temperature on oxygen uptake and nutrient flux in sediment inhabited by molluscs. Journal of Limnology, 72, 13-20. 